\title{
Ergotizmus v minulosti. Úloha námel’u v čarodejníckych procesoch a jeho využitie v medicíne v 19. storočí
}

\author{
Peter Ondreička \\ Fakulta humanitních studií, Univerzita Karlova, Pátkova 2137/5, 18200 Praha 8 - Libeň \\ Do redakce doručeno 21. ledna 2021; k publikaci přijato 15. června 2021
}

\section{ERGOTISM IN THE PAST. THE ROLE OF ERGOT DURING THE WITCH-HUNTS AND ITS USE IN THE MEDICINE IN $19^{\mathrm{TH}}$ CENTURY}

\begin{abstract}
The main aim of this article is to present the role ergot (as the cause of ergotism) has had in the past. This article will characterize ergotism and describe the historical context of the illness. In the first part we focus on the general characteristics of the ergot poisoning and its symptoms on man. Both forms of ergotism (convulsive and gangrenous) will be characterized. Based on the actual research in the field we will review the role of ergotism during the witch-hunts in early modern period. Second part of the article shows the different approaches of how the ergot was used in medicine and pharmacy in nineteenth century. The research is based on the contemporary articles in scientific magazines published in Czech lands, specifically Časopis lékařú českých, Zdravotnický věstník and Časopis českého lékarnictva. The article will show which effects the doctors in nineteenth century have thought the ergotism has, if they used it as the medicament and what other ways of use there were.
\end{abstract}

KEY WORDS ergot; ergotism; witchcraft; alkaloids; convulsions; claviceps purpurea

\begin{abstract}
ABSTRAKT Cielom tohto príspevku štúdie je ukázat', akú úlohu zohral námel ako pôvodca ergotizmu v minulosti. Štúdia prináša charakteristiku ergotizmu a dáva ergotizmus do historických súvislostí. V prvej časti sa zameriava na všeobecnú charakteristiku otravy námelom u človeka. Opisuje dve formy ergotizmu (konvulzívnu a gangrenóznu). Na základe doterajších výskumov zhodnotí rolu ergotizmu počas honov na čarodejnice v období ranného novoveku. Druhá čast’ práce prináša pohlad na využitie námelu v lekárstve a lekárenstve v 19. storočí. Text vychádza $\mathrm{z}$ dobových článkov vydávaných $\mathrm{v}$ odborných periodikách na českom území, konkrétne v Časopise lékařu českých, Zdravotnickém věstníku a Časopise českého lékarnictva. Prezentované je najmä, aké účinky lekári v 19. storočí námelu, ako pôvodcovi ergotizmu, pripisovali, či bol považovaný za liek a aké mal prípadné využitie.
\end{abstract}

KL'ÚČOVÉ SLOVÁ námel; ergotizmus; čarodejníctvo; alkaloidy; kŕče; kyjanička purpurová

\section{NÁMEL A ERGOTIZMUS}

Ergotizmus je choroba zavinená otravou námelom. Námel' (ražná hubka) je ochorenie rastlín spôsobené hubou Claviceps purpurea (Kyjanička purpurová). Rod Claviceps zahŕňa huby (fungi) žijúce v spojení s rastlinami, najmä trávami (Píchová et al. 2018, 73). Vyskytujú sa formy mutualizmu, endofytizmu aj parazitizmu na rôznych rastlinných častiach a orgánoch. $\mathrm{V}$ prírodných podmienkach má prítomnost' huby na kondíciu rastliny len minimálny vplyv, s výnimkou $C$. africana, $C$. sorghi a C. sorghicola ovplyvňujúcich produkciu semien ciroku. Claviceps purpurea je príbuzná s rodmi Aciculosporium, Epichloë, Balansia a Atkinsonella. Huby rodu Claviceps napadajú asi 1000 druhov rastlín, z rodu Gramineae, z ktorých množstvo patrí medzi potraviny konzumované človekom. Najčastejší výskyt kyjaničky purpurovej bol zaznamenaný na raži. Raž je, na rozdiel od iných obilnín, závislá na alogamii (oplodnení od iného jedinca), čo zvyšuje riziko prenosu nákazy na dalších jedincov (Duncan 1993, 30).

Dôležitejšia než vplyv na kondíciu rastliny je skôr schopnost 


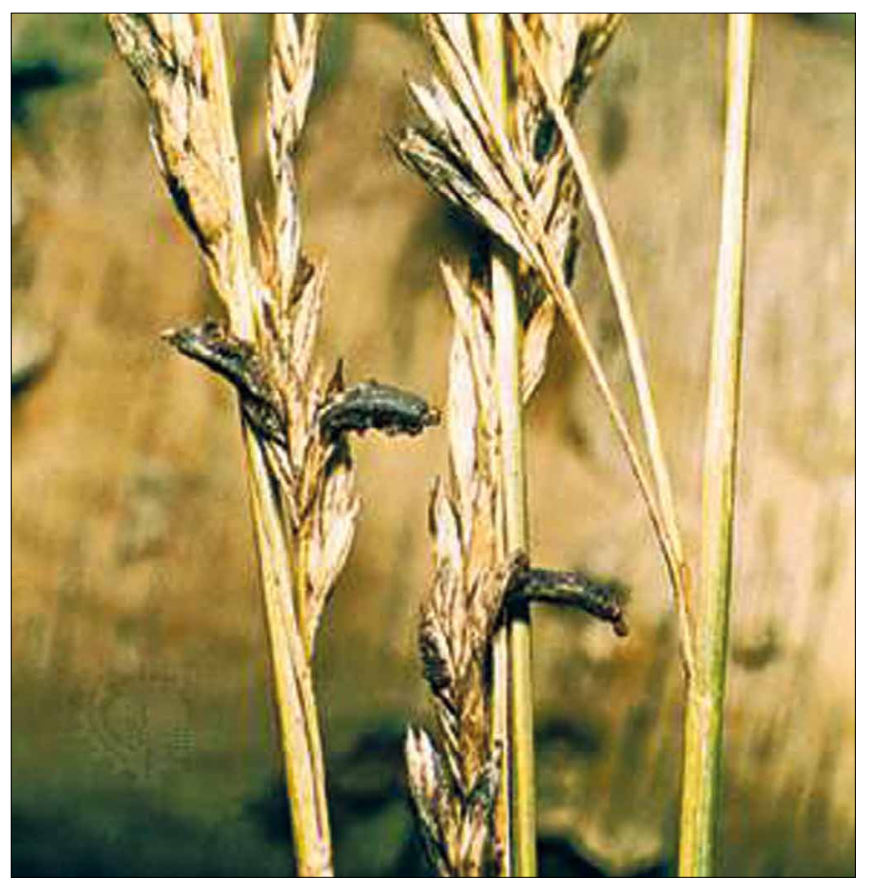

Obr. 1. Sklerócium kyjaničky purpurovej (námel). Zdroj: Ergot fungus. Encyclopedia britannica. (online). https://www.britannica.com/science/ergot-fungus.

týchto húb produkovat alkaloidy toxické pre cicavce. Alkaloidy ako klavíny a ergopeptíny spôsobujú u človeka ergotizmus (Píchová et al. 2018, 73). Kyjanička purpurová vytvára na obilí sklerócium, pevný tmavý útvar prežívajúci aj zimu a obdobie uskladnenia obilia. Známych je 40 ergotových alkaloidov obsiahnutých v skleróciu kyjaničky purpurovej (Mulac - Humpf 2011, 112). Okrem alkaloidov obsahuje sklerócium zásobné látky ako lipidy (asi $40 \%$ ). Zastúpenie alkaloidov v skleróciu je závislé na druhu zasiahnutej rastliny a geografickej oblasti (Dellafiora - Dall'Asta - Cozzini 2015, 535).

\section{PREJAVY ERGOTIZMU U ČLOVEKA}

Toxický účinok alkaloidov obsiahnutých v námeli je spôsobený ich podobnostou s niektorými neurostransmitermi (Mulac - Humpf 2011, 113). Kyjanička purpurová obsahuje toxické alkaloidy podobajúce sa svojou štruktúrou serotonínu. Rozlišujeme dva hlavné typy ergotizmu - konvulzívny a gangrenózny ergotizmus. Prevalencia danej formy je regionálne heterogénna. Konvulzívny ergotizmus sa vyskytoval v minulosti najmä v oblasti Porýnia, zatial čo gangrenózny najmä na území Francúzska (Alm - Elvevåg 2012, 16). Kovulzívny ergotizmus je spojený so spazmami, kŕčmi a epileptickými záchvatmi, kedže zasahuje najmä centrálnu nervovú sústavu. Alkaloidy obsiahnuté v námeli účinkujú na nervovú sústavu stimuláciou funkcie dopamínu, serotonínu a adrenalínu. Spôsobujú zmeny správania, depresie či dokonca smrt' (Alm - Elvevåg 2012, 20).

Gangrenózny ergotizmus zase zapríčiňuje problémy obehovej

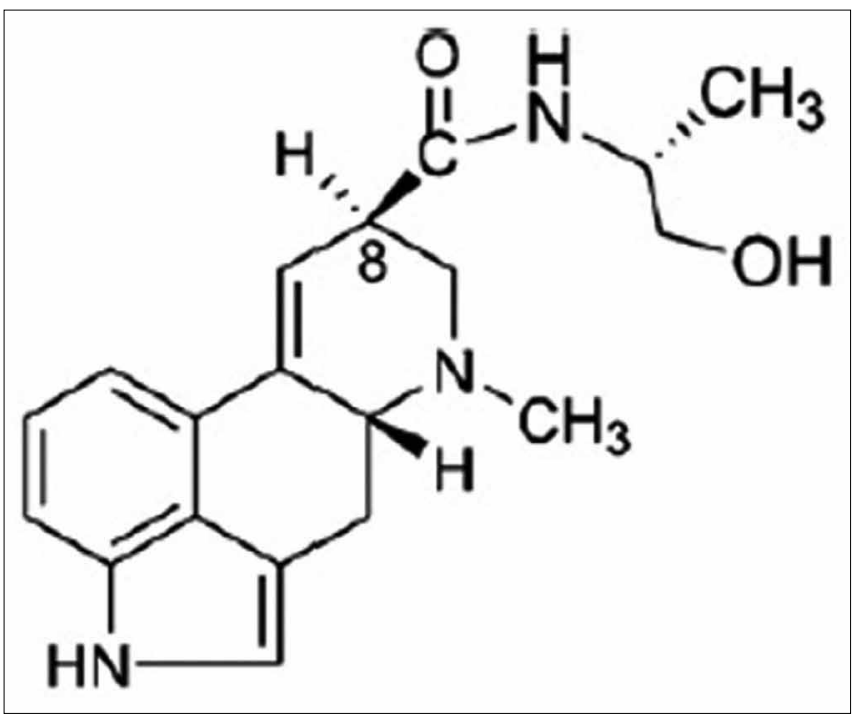

Obr. 2. Chemický vzorec ergometrinu (Zdroj: Mulac - Humpf 2011, 113).

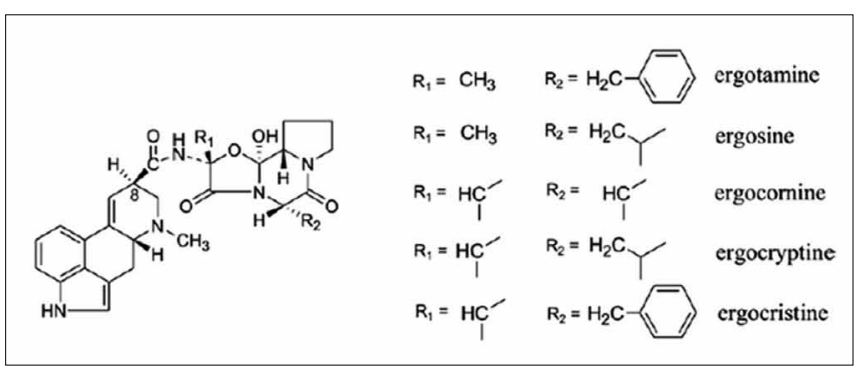

Obr. 3. Chemický vzorec peptidových alkaloidov obsiahnutých v námeli podielajúcich sa na ergotizme (Zdroj: Mulac - Humpf 2011, 113).

sústavy (Dellafiora - Dall'Asta - Cozzini 2015, 535). Je spôsobený ergotoxínom. Alkaloidy obsiahnuté v námeli vyvolávajú vasokonstrikciu a opakované užitie môže poškodit cievny endotel. To môže v konečnom dôsledku viest’ až k čiastočnej nekróze, najmä periférnych častí tela (Alm - Elvevåg 2012, 17). Prvé príznaky po konzumácií obilia zasiahnutého kyjaničkou purpurovou sa objavujú asi hodinu po užití (Alm - Elvevåg 2012, 17). Úvodnými príznakmi sú závrate, tlak v prednej časti hlavy, malátnost', nausea, depresie a bolesti v krížovej oblasti a v končatinách, čo môže viest' k problémom s chôdzou (Mastossian 1982, 355-357). Objavit’ sa môže zvýšené slinenie a potenie, silný smäd a nechutenstvo. Ak postihnutý jedinec pokračuje v konzumácií zasiahnutého obilia, môžu tieto symptómy trvat niekol'ko týždňov. Postupom času sa objavujú dalšie príznaky. Rozprávanie je stažené a zmysly otupené, reakcie aj na bolestivé vnemy sú slabšie. Ak bola koža na periférnych častiach tela (ako ruky a chodidlá) studená, znamenalo to poškodenie ciev a začiatok gangrény (Alm Elvevåg 2012, 17). Pri vážnejších prípadoch ergotizmu dochádza $\mathrm{k}$ pocitom mravenčenia, kontrakciám svalov, tonickým spazmám $\mathrm{v}$ končatinách a $\mathrm{v}$ tvárových svaloch. Niekedy dochádza $\mathrm{k}$ prerušeniu močenia. $\mathrm{V}$ najvážnejších prípadoch trpí postihnutý epileptickými kŕčmi. $\mathrm{V}$ taktom prípade do- 
chádza k smrti po troch dňoch od objavenia sa prvých príznakov. Náchylnejšie na otravu sú deti a adolescenti (Matossian 1982, 355-357). Halucinácie spôsobuje kyselina lysergová, ktorá je základom pri výrobe LSD (Alm - Elvevåg 2012, 19). Halucinácie sa môžu vyskytnút pri oboch formách ergotizmu. Rozdielne príznaky jedincov postihnutých ergotizmom je možné vysveltit’ odlišným zastúpením jednotlivých alkaloidov v tele huby. Pomer alkaloidov je regionálne závislý (Matossian 1983, 35).

\section{NÁMEL A ČARODEJNÍCKE PROCESY}

Konvulzívny ergotizmus je často spájaný s čarodejníckymi procesmi. Po stredovekom teplom období sa podnebie v Európe začalo zhoršovat. Toto obdobie, označované ako Malá doba ladová, bolo charakteristické ochladením a zvýšeným množstvom zrážok. Suché a horúce letá sa striedali s dlhou a studenou zimou. Vyskytovali sa záplavy, búrky a krupobitia poškodzujúce úrodu (Behringer 2016, 162). Intenzívny vplyv Malej doby ladovej sa prejavil po roku 1560 nasledovaný celoeurópskym mohutným nárastom prenasledovania čarodejníc v 80. rokoch 16. storočia (Behringer 2002, 69-87). Pre rozvoj kyjaničky je ideálna studená zima nasledovaná chladným a daždivým obdobím rastu rastlín. Chladné počasie oslabuje hostitel'skú rastlinu, vlhkost' zase podporuje rast huby (Alm - Elvevåg 2012, 17). Obdobie Malej doby ladovej tak predstavovalo ideálne obdobie na šírenie tohto hubového ochorenia. Z obdobia prenasledovania čarodejníc sa zachovali výpovede údajne očarovaných osôb. Ich správanie, resp. problémy ktorými trpeli, opísané pri niektorých procesoch sa niekedy teoreticky zhodujú s príznakmi vyvolanými ergotizmom. Ergotizmus spôsobuje st̉aženie rozprávania a halucinácie, ktoré tiež mohli byt' spolu s kŕčmi chápané ako príznaky očarovania (Alm - Elvevåg 2012, 23).

Súvislost' ergotizmu a čarodejníckych procesov sa do povedomia odbornej aj širšej verejnosti dostala najmä vdaka hypotéze súvislosti ergotizmu a známych čarodejníckych procesov v Saleme (Massachusetts, USA) z roku 1692. Išlo o najhorší hon na čarodejnice na území dnešných Spojených štátov amerických. Dlho ostávala nezodpovedaná otázka, prečo takáto hystéria vypukla práve $\mathrm{v}$ tejto lokalite a práve $\mathrm{v}$ roku 1692 (Matossian 1982, 355-357). V roku 1976 prišla Linda Caporael, študentka psychológie na Kalifornskej univerzite v Santa Barbare s teóriou, že hon na čarodejnice v Saleme podnietil ergotizmus (Godbeer 2013, 402). Novšie výskumy však túto teóriu vyvrátili a ich závery nasvedčujú, že príčina Salemských procesov bola komplexnejšia. Úlohu zohral najmä sociálny konflikt, externé vplyvy (napr. útoky Indiánov, ktoré obyvatel'stvo prisudzovalo diablovi) a dobová religiozita v danej oblasti (Godbeer 2013, 404).

Spájanie ergotizmu a honov na čarodejnice je v súčasnej dobe odborníkmi všeobecne posudzované opatrne. Takáto súvislost' je často založená len na odhadoch, kedže ku konkrétnym prípadom sú len zriedka k dispozícií záznamy o zdravotnom stave alebo záznamy o strave (Norton 2003, 9; Burns 2003,
194; Goodare 2006, 321). Na druhú stranu sú známe aj prípady, kedy sa pri opise procesov zachovali aj bližšie informácie. Napr. Alm - Elvevåg uvádzajú, že pri procesoch z roku 1634 vo Finnmarku (Nórsko) mala obet’ čarodejníctva namodralé časti tela a prišla o hornú končatinu (Alm - Elvevåg 2012, 24) a v d’alších procesoch bola explicitne uvedená konzumácia potravín vyrobených z čierneho obilia, čo autori v oboch prípadoch dávajú do súvislosti s ergotizmom (Alm - Elvevåg 2012, 23).

\section{NÁMEL' A MEDICÍNA}

\section{VÝSKUM A INTERPRETÁCIA OCHORENIA}

Účinky otravy spôsobenej nakazeným obilím sa počas minulosti interpretovali rôzne. Ergotizmus bol označovaný ako ignis sacer (Alm - Elvevåg 2012, 15). Spojenie ergotizmu s ohňom vzniklo kvôli spalujúcej bolesti v končatinách. Po vypuknutí gangrény boli zčernalé údy prirovnávané $\mathrm{k}$ uhliu (Cameron - French 1960, 28).

Počas histórie sa viacero vedcov pokúsilo identifikovat' zložky ergotizmu. Alkaloid ergotinin bol separovaný v roku 1875 Francúzom Charlesom Tanretom. Úplnú chemickú štruktúru ergotizmu opísal v roku 1951 Albert Hoffmann. John Moir vykonal experiment, počas ktorého meral intenzitu stahov maternice. Zaznamenal výraznú reakciu po orálnom podaní námelu v intenzite aj rýchlosti stahov. Po dalšom výskume sa v roku 1935 podarilo extrahovat čistý ergometrin a preukázat', že práve ergometrin je účinnou látkou námelu ovplyvňujúcou činnost' maternice (Sneader 2005, 342).

\section{EPIDÉMIE ERGOTIZMU}

V odbornej literatúre nie je zhoda, kolko epidémií ergotizmu sa počas histórie vyskytlo. Alm a Elvevåg odhadujú, že od roku 945 sa v rôznych častiach Európy vyskytlo 83 epidémii ergotizmu (Alm - Elvevåg 2012, 16). Otter tvrdí, že medzi rokmi 591 až 1789 vypuklo v Európe 132 epdidémií (Otter 2015, 751). Najväčšie epidémie ergotizmu zasahovali územie dnešného Francúzska a Nemecka (Stockman 1934, 235). Mortalita postihnutých ergotizmom $\mathrm{v}$ rannom novoveku predstavovala 10 až $20 \%$ (Matossian 1983, 34). Posledné velké epidémie ergotizmu vypukli v Etiópii v rokoch 1978 a 2001 a v Indii v 70. rokoch 20. storočia (Píchová et al. 2018, 73).

Skutočnosti, že otrava námel'om môže dosiahnut až rozmery epidémie, si boli vedomí aj odborníci v 19. storočí. V roku 1883 bol publikovaný článok vychádzajúci z výskumu A. Poehla ohladne hnitia žitnej múky a vplyvu týchto procesov na vypuknutie epidémie ergotizmu. Autor článku upozornil, že epidémie ergotizmu nastali vždy po daždivých obdobiach alebo povodniach. Úmrtnost' počas týchto epidémií dosahovala úroveň 1:1,75 až 1:4. Úmrtnost' bola dva krát vyššia u detí než u dospelých (Bělohoubek 1883, 745). 
Epidémie námelu sa nevyhli ani územiu habsburgskej monarchie. Dňa 7. 7. 1895 vydal český miestodržitel’ pokyn na prešetrenie, či sa vyskytli otravy námel'om v halíčskych okresoch, kedže viacero osôb po konzumácií chleba ochorelo a vykazovali príznaky ergotizmu (Zdravotnický věstník 1895, 57). Vyšetrovaním sa zistilo, že do Halíča aj Čiech bolo dovezené postihnuté obilie, čo spôsobilo viacero prípadov ergotizmu a niekolko úmrtí. Rolníkom bolo opätovne nariadené očistit obilie od všetkých nečistôt a mlynárom bolo zakázané mliet' znečistené obilie (Zdravotnický věstník 1896, 45-46).

\section{PÔVOD NÁMELU}

Pôvod námelu bol do 18. storočia vysvetlovaný rôzne. Jednou $\mathrm{z}$ teórií bolo, že sladká tekutina tvoriaca sa na námeli pred utvorením sklerócia bola produktom kvasenia (Senft $1897,101)$. Jandouš píše, že na žite sa tvorila lepkavá a sladká hmota, medová rosa. V nej bolo možné pod mikroskopom rozoznat oválne bunky. Po šiestich dňoch sa táto zmes sfarbila do fialova, zatvrdla a premenila sa tak na námel' (Jandouš $1862,107)$.

Iná teória vysvetlovala vznik námelu uštipnutím chrobáka Cantharis melanura (Senft 1897, 101). Teóriu o bodnutí hmyzom potvrdzuje napríklad článok $\mathrm{z}$ roku 1863, podla ktorého vývin námelu začína bodnutím chrobáka rhagonycha melanura. Tento chrobák sa podla autora objavoval vo vel'kom množstve každý rok. Po odkvitnutí žita sa usádzal na klasy, aby vysával štavu zo zŕn. Zo zrna potom vytekala nepríjemne zapáchajúca lepkavá tekutina, po stvrdnutí vytvárajúca námel' (Jandouš 1863, 151).

V 19. storočí medzi vedcami prebiehala diskusia, či je námel formou plodu alebo ide o pleseň. V roku 1865 Münchhausen identifikoval za pôvodcu námelu hubové ochorenie (Senft $1897,101)$. Ako píše Jandouš, v druhej polovici 19. storočia už bola teória o vzniku námelu premenou plodu dlhší čas vyvrátená. Našli sa však aj vedci snažiaci sa stále túto teóriu dokázat'. Dr. Flückiger z Bernu sa preto experimentom snažil obhájit pôvod námelu ako plesňovitého ochorenia. Aby sa preukázal pôvod námelu, dr. Flückiger a prof. Fisher zasadili samostatne na dvoch rôznych miestach rovnaký námel. Po asi troch mesiacoch sa na povrchu pôdy objavili hlavičky plesne claviceps purpurea (Jandouš 1866, 123).

\section{NÁMEL V KLINICKEJ PRAXI}

Podla Sneadara sa námel používal pri pôrodoch už v období raného novoveku. Ako príklad uviedol knihu Adama Lonicera Kreuterbuch, vydanú v roku 1582 vo Frankfurte nad Mohanom. V nej Lonicer uviedol, že pôrodné babice používali tzv. Kornzapfen, aby urýchlili pôrod. Kornzapfen považoval Sneader za námel'. V roku 1808 sa správa Johna Stearnsa o použití námelu na urýchlenie pôrodných bolestí objavila prvý raz $\mathrm{v}$ americkom vedeckom časopise Medical Repository. Definitívne bol vedeckou obcou námel' uznaný za liečebný prostrie- dok po prednáške Olivera Prescotta publikovanej v roku 1813 (Sneader 2005, 341).

V dobových článkoch môžeme nájst’ viacero možností, ako bol námel’ používaný. Najčastejšie bol námel' využívaný v gynekológií. Čeňek Křížek v článku $O$ nepravidelnostech ve výkonech dělohy při porodu uviedol, že v danej dobe stál námel' na prvom mieste medzi liekmi podávanými pri pôrode na činnost' maternice. Musel byt podávaný opatrne, $\mathrm{v}$ malých dávkach a len počas kratšej doby. Podla autora nesmel byt' námel' podávaný pri zúženej panve, nepravidelných srdcových odozvách plodu ani pri horúčke (Křížek 1875, 292).

Nebezpečenstva hroziaceho pri podaní námelu si boli doboví lekári vedomí. Prof. Braun označil použitie námelu spolu s púštaním žilou za prostriedky najviac ohrozujúce život dietata a matky pri pôrode. Námel' síce zosilnil pôrodné bolesti, ale stiahnutím ciev obmedzil prívod krvi do maternice. Dôsledkom bolo síce slabšie krvácanie, ale podla Brauna sa zároveň narušil prívod krvi $\mathrm{k}$ plodu. To mohlo viest' $\mathrm{k}$ asfyxii a následnému úmrtiu plodu. Pri vyššej dávke námelu (viac než 2 až $4 \mathrm{~g}$ denne) nastávalo, podla pozorovania autora, ochrnutie maternice a dolných končatín. Preto mal byt námel’ používaný len pri fázach pôrodu, kedy sa očakávalo narodenie dietata do hodiny, pričom bolo potrebné sledovat' srdce novorodenca. Námel’u tiež nebolo možné priznat zásluhu za rýchlejší pôrod. Odporúčal námel' použit len $\mathrm{v}$ prípade krvácania po potrate alebo pôrode mŕtveho plodu (Braun 1880, 172). Podobne Eiselt tvrdil, že otravy námel'om mali okrem ekonomického pôvodu, spôsobeného konzumáciou nakazeného obilia (namiesto jeho likvidácie) aj medicínsku príčinu spôsobenú podaním príliš vel'kej dávky liečiva. Avšak ergotizmus medicínskeho pôvodu bol vzácnejší (Eiselt 1884, 869). Námel' bol používaný nielen pri pôrode, ale aj ako prostriedok na zabezpečenie potratu v ludovom liečitel'stve, napr. v Rusku (Děmič $1889,586)$. Námel’ sa v lekárstve začal používat' vo väčšej miere po roku 1840 (Jandouš $1880,312-313$ ).

O ergotinine bolo známe, že znižuje teplotu, spomaluje tep, stahuje cievy a účinkuje na svalové vlákna. Mohol spôsobit’ nauseu, vracanie a hnačky. Pri niektorých rodičkách s vyššou citlivostou na ergotinin sa mohli vyskytnút vracanie a známky otravy už po podaní dávky $1 \mathrm{mg}$ (Časopis českého lékárnictva 1885b, 130).

V roku 1863 uverejnil v Časopise lékařú českých článok pražský praktický lekár Adolf Dub, v ktorom upozornil na epidémiu ergotizmu z roku 1854. Táto vlna ergotizmu vypukla v oblasti Golčova Jeníkova (ned’aleko Čáslavy, pozn. autora) kvôli vel’mi daždivému počasiu počas roku 1854. Námel' postihol žito. Epidémia spôsobila aj viacero úmrtí. Dr. Dub napísal, že od tejto epidémie začal, ak to bolo bezpečné, podávat malé množstvá námelu svojim pacientom. Námel’ podla dr. Duba spôsoboval kontrakcie svalov, čo bolo viditelné najmä pri krvácaní. Platilo to aj pre srdce, ktorého objem sa podla dr. Duba následne zmenšil aj na niekolko dní. U pacientov bez srdcových ochorení sa pôvodný srdcový objem navrátil do troch dní. Podla autora bol námel' prospešnejší než iné liečivá (digitalis a chinín), pri chorobách srdca aj v prípade, že boli spojené s edémom končatín. Námel’ totiž podla autora 
zlepšil obeh krvi. V prípade neurologických ochorení ako ischias nezaznamenal autor žiadne účinky námelu. Námel' bol však podla autora prospešný pri ochoreniach maternice. Autor podával, podla neho s úspechom, námel’ aj pri zápale plúc, chrlení krvi a tuberkulóze. Hlavným kladom podla autora bolo spomalenie pulzu (Dub 1863, 185).

$\mathrm{V}$ dalšom článku, uverejnenom v roku 1885 bez uvedeného autorstva, sa dozvedáme, že hlavným účinkom použitia námelu bolo spustenie stahov maternice. Ak sa podávali pacientovi každé dve hodiny $2 \mathrm{~g}$ ergotinu a to bez ohladu na vek, jeho pulz sa spomalil o 10 až 36 tepov. Nepravidelný pulz sa stával pravidelnejším. Podávaný liek spôsoboval problémy pri chôdzi a často zvracanie, hlavne ak sa podala väčšia dávka. Autor článku dalej priniesol opis stavu osôb, ktorým bol námel' podávaný dlhšiu dobu. Najprv sa u nich vyskytol stav podobný opitosti. Následne sa začali týmto pacientov upchávat' cievy, čo viedlo ku gangréne. Autor poznamenal, že pacientom doslova „odpadávali končatiny“. Autor poznamenal, že takéto príznaky sa preto nazývali ergotismus gangraenosus. Druhou formou bol ergotismus convulsivus charakteristický kŕčmi a závratou. Kedže sa však nevyskytoval nikdy $\mathrm{v}$ rovnakom čase a na rovnakom mieste ako gangrenózny ergotizmus, autor sa domnieval, že táto choroba nebola spôsobená námel’om. Mohla byt' podla neho spôsobená múkou, do ktorej boli primiešané semená rastlín raphanus raphanistrum (redkev ohnicová - burina vyskytujúca sa na obilných poliach, pozn. autora) alebo lolium temulentum (mätonoh mámivý - v minulosti burina, pozn. autora); (Časopis lékařú českých 1870, 371-374). Ergotin bol extrahovaný Wenzellom vo Wisconsine v 60. rokoch 19. storočia (Časopis českého lékárnictva 1885, 46).

V krátkej správe v roku 1871 uverejnenej v Časopise lékařú českých bolo citované odporúčanie dr. Rotha používat námel’ pri ochrnutí močového mechúra spôsobeného prechladnutím alebo dlhým zadržiavaním moču. Roth podával s dobrým výsledkom dávku 0,5g námelu štyri krát denne (Časopis lékařú českých 1871, 392).

Námel' bol svojho času významnou komoditou. Od roku 1883 bol výnosom ministra vnútra predaj námelu na území rakúskej časti habsburgskej monarchie povolený len lekárnikom. Navzdory tomu podla Prúška bujnel aj nelegálny obchod s námelom. Kilogram sa predával v roku 1892 za 2,5 zlatých, čo viedlo niektorých obchodníkov v snahe po vyšších ziskoch $\mathrm{k}$ tomu, že nafarbili obyčajné obilie a predávali ho ako námel' (Prúšek 1893, 412). Niektorí rolníci, aj ked'si boli nebezpečenstva námelu vedomí, ho z ekonomických dôvodov podávali ako krmivo zvieratám alebo ho použili ako hnojivo. To však mohlo viest' o rozširovaniu námelu v dalších rokoch. Niekedy dokonca malé množstvo námelu radšej skonzumovali, než by obilie vyhodili (Voráček 1894, 17). Námel’ sa však pestoval aj cielene. Podla Voráčka nevyžadovalo pestovanie námelu vyššie náklady ani viac času než pestovanie obilia. Neusušený námel' zozbieraný z obilia sa zmiešal s hlinou a zasial sa do vyhlibených brázd. Po preoraní sa dostalo sklerócium do hlbších častí pôdy, kde prezimovalo. Jarným oraním sa zase dostalo do vyšších častí pôdy, čím bolo ulahčené klíčenie. Vedla plo- chy osiatej námel’om sa malo zasadit žito, na ktorom potom huba parazitovala (Voráček 1894, 17).

$S$ použitím námelu experimentovali francúzski lekári pri epidémiách týfusu. Francúzsky lekár Duboué skúšal námelom liečit týfus u 36 pacientov, z toho 11 malo velmi tažký a d’alších 14 tažký priebeh ochorenia. Zomreli dvaja pacienti. Účinky námelu hodnotili, podla autora článku uverejneného $\mathrm{v}$ roku 1877, pozitívne aj d’alší francúzski odborníci. Námel' mal znížit krvácanie, skrátit trvanie choroby a znížit úmrtnost' (Maixner $1884,98)$. Námel' podával pri týfuse aj Hérard, avšak len niekolkým najtažším prípadom (Časopis lékařú českých 1882, 762). Námelom sa niektorí odborníci snažili liečit cukrovku (diabetes mellitus). Námel' vraj použil lekár Hasse na dvoch pacientoch s dobrým výsledkom (Janovský 1877, 383).

\section{ZÁVER}

V práci sme ukázali vlastnosti námelu a jeho účinky na ludský organizmus. Niektoré príznaky ergotizmu zodpovedajú príznakom údajne očarovaných osôb $\mathrm{z}$ doby velkých honov na čarodejnice $\mathrm{v}$ ranom novoveku. To viedlo niektorých autorov hladajúcich príčinu konkrétnych procesov k záverom, že niektoré hony na čarodejnice vyvolali v skutočnosti epidémie ergotizmu. Na základe najnovších poznatkov sme preto poukázali na fakt, že tieto závery nie sú často podložené empirickým výskumom a sú skôr v rovine hypotéz. V druhej časti štúdie sme na dobových článkoch uverejnených v odborných lekárskych alebo lekárnickych periodikách ukázali rôzne spôsoby využitia námel’u v klinickej praxi v minulosti. Predstavili sme vývoj teórií o vzniku námelu na obilí a poukázali na zdržanlivost’ niektorých lekárov k používaniu námelu $\mathrm{z}$ dôvodu hroziacej otravy.

\section{PRAMENE}

Bělohoubek (1883): O ergotismu. Časopis lékařú českých, 22(47), 745-748. Braun, C. (1880): Nemoci dětské, ženské a porodnictví. Časopis lékařú českých 19(11), 171-173.

Děmič, V. F. (1889): Nástin ruské prostonárodní medicíny. Časopis lékařú českých, 28(30), 586-588.

Dub, Adolf (1863): Něco o námelu. Časopis lékařú českých, 2(14), 185-186.

Eiselt, Jan Bohumil (1881): Odborná pathologie a therapie III. Praha: Knihtiskárna Františka Simáčka, $1004 \mathrm{~s}$.

Jandouš, Alois (1862): Secale cornutum (námel) a ergotin, Časopis lékařú českých, 1(8), 107-108.

Jandouš, Alois (1863): Jak se tvoří námel. Časopis lékařú českých, 2(12), 151152.

Jandouš, Alois (1866): Něco o námelu. Časopis lékařú českých, 5(16), 123.

Jandouš, Alois (1880): Ergotínové preparáty. Časopis lékařú českých, 19(20), $312-313$.

Janovský, (1877): O léčení úplavice cukrové. Časopis lékařú českých, 16(48), 382-383.

Křrižek, Čeněk (1875): O nepravidelnostech ve výkonech dělohy při porodu. Časopis lékařú českých, 37(14), 292-296.

Maixner (1884): b. n. Časopis lékařú českých, 23(7), 97-99.

Prúšek, Fr. (1893): Obchod s námelem. Časopis českého lékárnictva, 12(26), 411-412.

Senft, E. (1897): O námelu. Časopis českého lékárnictva, 16(8), 101-102. 
Voráček, Martin (1894): Pěstovaní námele (secale cornutum). Časopis českého lékárnictva, 13(2), 17-19.

Secale Cornutum (1870). Časopis lékařú českých, 9(47), 371-374.

Námel (1871): Časopis lékařú českých, 10(49), 392.

Nemoci vnitřní (1882): Časopis lékařú českých, 21(48), 762-763.

O součástech a účincích námele (1885a). Časopis českého lékárnictva, 4(4), $44-48$.

Cornutin a ergotinin (1885b): Časopis českého lékárnictva, 4(9), 129-130.

Zdravotnický věstník; př́loha Časopisu lékařu českých věnovaná veřejnému zdravotnictví : orgán lékařské komory pro Král. České (1895). 7(8), 57.

Zdravotnický věstník; př́loha Časopisu lékařu českých věnovaná veřejnému zdravotnictví : orgán lékařské komory pro Král. České (1896). 8(5), 45-46.

\section{LITERATÚRA}

Alm, Torbjørn - Elvevåg, Brita (2012): Ergotism in Norway: The symptoms and their interpretation from the late Iron Age to the seventeenth century. History of Psychiatry, 24(1), 15-33.

Behringer, Wolfgang (2002): Weather, Hunger and Fear: Origins of the European Witch-Hunts in Climate, Society and Mentality. In: Oldridge, Darren, ed., The witchcraft reader, New York: Routledge, 69-87.

Behringer, Wolgang (2016): Čarodějnictví: Globální historie. Praha: XYZ.

Burns, Wiliam (2003): Witch hunt in Europe. Westport: GreenwoodPress.

Cameron, E. A. - French, E. B. (1960): St. Anthony‘s Fire Rekindled: Gangrene Due To Therapeutic Dose Of Ergotamine. The British Medical Journal, Vol. 2, 2(5191), 28-30.

Dellafiora, Luca - Dall'Asta, Chiara - Cozzini, Pietro (2015): Ergot alkaloids: From witchcraft till in silico analysis. Multi-receptor analysis of ergotamine metabolites. Toxicology Reports 70(2), 535-545.

Duncan, Kirsty (1993): Was ergotism responsible for the Scottish witch -hunts? Area, 25(1), 30-36.

Godbeer, Richard (2013): Witchcraft in British America. In: Levack, Brian, ed., The Oxford Handbook of Witchcraft in Early Modern Europe and Colonial America, Oxford: Oxford university press, 393-412.

Goodare, Julian (2006): Ergotism. In: Golden, Richard, ed., Encyklopedia of Witchcraft - Western Tradition, Santa Barbara: ABC-CLIO, 321-322.
Matossian, Mary (1982): Ergot and the Salem Witchcraft Affair: An outbreak of a type of food poisoning known as convulsive ergotism may have led to the 1692 accusations of witchcraft. American Scientist, 70(4), 355-357.

Matossian, Mary (1983): Bewitched or Intoxicated? The Etiology of Witch Persecution in Early Modern England. Medizinhistorisches Journal, 18(1), 33-42.

Mulac, Dennis - Humpf, Hans-Ulrich (2011): Cytotoxicity and accumulation of ergot alkaloids in human primary cells. Toxicology (282), 112-121.

Norton, Mary Beth (2003): Witchcraft in the Anglo-American Colonies. Magazine of History 17(4), 5-11.

Otter, Chris (2015): Toxic Foodways: Agro-Food Systems, Emerging Foodborne Pathogens, and Evolutionary History. Environmental History, 20(4), 751-764.

Píchová, Kamila et al. (2018): Evolutionary history of ergot with a new infrageneric classification (Hypocreales: Clavicipitaceae: Claviceps). Molecular Phylogenetics and Evolution 123(b. č.), 73-87.

Sneader, Walter (2005): The drug discovery. Chichester: John Wiley \& Sons Ltd, $468 \mathrm{~s}$.

Stockman, Ralph (1934): The Cause of Convulsive Ergotism. The Journal of Hygiene, 34(2), 235-241.

Online zdroje

Ergot fungus. Encyclopedia britannica. (online). https://www.britannica. com/science/ergot-fungus.

\section{AUTOR}

Ondreička, Peter, Mgr. et Mgr. (* 1992, Trenčín) je absolventom magisterského štúdia histórie na Univerzite Komenského v Bratislave a antropológie na Masarykovej univerzite v Brne. Momentálne pôsobí ako doktorand na obecné antropologii na Fakultě humanitních studií Univerzity Karlovy. Zameriava sa na čarodejnícke procesy počas raného novoveku, posadnutie a konflikt modernity a poverčivosti $\mathrm{v} 19$. storočí.

Kontakt: ondreicka.ptr@gmail.com 